УДК 811.131.1'373.613:070

DOI 10.37972/chgpu.2021.112.3.014

A. G. Sokolova

\title{
STUDY OF PRAGMATIC ASPECTS OF ANGLICISMS IN ITALIAN MEDIA TEXTS
}

\author{
National Research Moscow State University of Civil Engineering, \\ Moscow, Russia
}

\begin{abstract}
This article considers the study of Anglicisms in contemporary Italian media texts as well as their characteristics and pragmatic potential. The relevance of the research lies in the implementation of cognitive analysis of semantics and pragmatics of Anglicisms and identifying cognitive and pragmatic rules of their use in modern Italian media reports. Having applied descriptive method, comparative and stylistic analyses, contextual and pragmatic analyses, the author attempted to research the archives of three national broadsheet newspapers and web-based English and Italian corpora. Journalists use borrowings for introducing new denotative meanings and evoking certain emotions and feelings of the potential readership. Contemporary Italian media text transmits a personal message of an author that is distinguished from the proper connotation and denotation of a term used in a source language. The principal motives for borrowings' use in the Italian press comprise the tendency to fill the gaps with foreign labels and tags. It was concluded that the majority of the borrowings are attributed to the sphere of politics, economy, labour and commerce, information technologies, fashion, entertainment, music, and sport.
\end{abstract}

Keywords: Anglicism, borrowings, pragmatic analysis, Italian media texts, cognitive linguistics, assimilation.

А. Г. Соколова

\section{ИЗУЧЕНИЕ ПРАГМАТИЧЕСКИХ АСПЕКТОВ АНГЛИЦИЗМОВ В ИТАЛЬЯНСКИХ МЕДИАТЕКСТАХ}

\author{
Национальный исследовательский Московский государственный \\ строительныгй университет, г. Москва, Россия
}

\begin{abstract}
Аннотация. Статья рассматривает изучение англицизмов в современных итальянских медиатекстах, а также их характеристики и прагматический потенциал. Актуальность исследования заключается в проведении когнитивного анализа семантики и прагматики англицизмов и установлении когнитивных и прагматических правил их использования в сообщениях средств массовой информации. Автор изучал архивы трех основных национальных итальянских широкоформатных газет и электронные корпусы английского и итальянского языков, применяя описательный метод, а также сравнительный и стилистический анализ, контекстуальный и прагматический анализ. На основании проведенных исследований был сделан вывод о том, что журналисты используют заимствования для введения новых денотативных значений и для возбуждения определенных эмоций и чувств у потенциальных читателей. Современные итальянские медиатексты передают личное сообщение автора, в котором коннотация и денотат заимствованного термина отличны от коннотации и денотата, принятых в языке-доноре. Основной причиной заимствований в итальянской прессе является тенденция заполнить имеющиеся лакуны иностранными понятиями и тегами. Автор пришел к заключению, что подавляющая часть заимствований относится к сфере политики, экономики, труда, коммерции, информационных технологий, моды, индустрии развлечений, музыки и спорта.
\end{abstract}

Ключевые слова: англицизм, заимствования, прагматический анализ, итальянские медиатекстьл, когнитивная лингвистика, ассимиляция. 
Introduction. The subject of the research is linguistic borrowings of English and American terms - assimilated words, neologisms, semantic and syntactic calques (loan-words), etc. The objective of the researchis to study English and American linguistic borrowings, as well as their characteristics and pragmatic potential, which can be found in Italian mass media reports.

Relevance. Relevance of the researched problemlies in the fact that the cognitive analysis of semantics and pragmatics of Anglicisms of various assimilation degree was implemented for Italian media texts; the cognitive and pragmatic rules defining the use of Anglicisms in modern Italian language were identified.

Materials and methods. The research is conducted on the material of the archives of three best-selling Italian newspapers, such as Corrieredella Sera (CS), La Repubblica (LR) and La Stampa $(L S)$, as well as a web-based Italian corpus it TenTen, a web-based English corpus enTenTen, corpora of English language, English monolingual dictionaries, dictionaries of English and Italian idioms, and Italian-English bilingual dictionaries. For analysing material, the following methods are used: a descriptive method, comparative analysis, stylistic analysis, contextual analysis, and pragmatic analysis.

Results and Discussion. From a broad perspective, borrowing could be viewed as a part of a wider linguistic phenomenon called neology that incorporates all the processes determining the formation of new words in a language vocabulary. Every natural language is predisposed to neologism creation, either by importing and adopting them from other linguistic systems, or by creating them out of own language resources. Social evolution of humankind preconditioned the neology process by means of introduction of new inventions, advances, phenomena, products, that is inevitably followed by emerging of new words. Neologism is regarded as a new word or a new phrase in a language with a highly uncertain destiny, i.e. either the receptor language will accept it in its vocabulary or reject from its linguistic system $[1$, p. 6].

Despite the fact that Johannes Gutenberg had revolutionized the diffusion of texts through the printed press before 1500 , the written texts did not manage to reach all the classes of society. However, written texts started their ascent towards augmentation of power and impact on society, whereas the borrowings diffused into the Italian language primarily via written texts and later transferred into the spoken language [4, p. 109].

In the 1950s, the Italian language became a stage of various linguistic phenomena, with prolonged statutory education and substitution of French by English as a principal foreign language taught in schools. In addition, English started its penetration via mass media - the cinematograph of the 1900s, the radio of the 1920s, and the TV in 1957 [5, p. 95]. As far as the world of radio broadcasting is concerned, it was initially based on the written texts pronounced in a unified and crystallized way, without any particular regional traces. Radio sport programs in those years served as a platform for pure improvisation, foreign words and expressed emotions. The world of cinematograph was experimenting with the foreign influx, when American movies were flooding the market. Photographic films, especially popular thanks to their simple and entertaining structure, allowed the audience to escape from the personal problems instantly, as opposed to the national films that touched upon the social realistic problems. Due to the low literacy rate of the population, the dubbing of the films was a necessity, thus limiting the number of borrowings entering the language via films. According to the data provided by the IstitutoNazionale di Statistica (En. National Institute of Statistics), the population's illiteracy rate accounted for $12.9 \%$ in the postwar years. The labor market of interpreters engaged in cinematograph preconditioned the variable quality of translation. The vivid example is the translation of the English word trivial (meaning unimportant, insignificant, inconsequential, minor) as triviale in Italian (meaning vulgar, rude, ill-mannered, disrespectful), with the total change of the meaning not intended by the film director [9, p. 122]. 
The TV has also started in a similar way to the radio, not marked with dialects, community languages, or foreign influence. However, the situation changed dramatically during the second half of the twentieth century. In the 1980s, the influx of borrowings increased immensely due to the popularity of Northern American TV series. In the 1990s, with explosion of the internet, email and other media of communication, Anglicisms found new entries to the Italian society. With the course of time and diffusion of mass media, borrowings in general and Anglicisms in particular have diffused in all the territory of Italy and penetrated all social classes. People who had never experienced any contacts with foreigners became closer to the rest of the globe thanks to mass media and social networks [6, p. 221]. The opinions about the commencement of globalization process differ: some scientists believe it started during the epoch of Cristopher Columbus and the discovery of America, while the others suggest that globalization is a relatively recent phenomenon of the last 100 years preconditioned by significant reduction of the goods shipment costs. In other words, globalization has changed the world not only at a global scale but also in the linguistic field.

Printed press serving as a means of rapid diffusion of Anglicisms in all the classes of Italian society has become an evident and important factor whereas due to globalization Anglicisms have reached much more people and their number has plummeted. New terms, notions and expressions have entered the reality of life, especially when some top-selling newspapers, like Corrieredella Sera, strengthened their position by issuing Italian and English versions [10, p. 30].

With breaking news emitted with lightning speed and extreme urgency, journalistic rushing laid the grounds for new ways of communication and created the need for naming new phenomena not yet translated into the recipient language or culture-specific units. It is signifier not signified that is absent in the recipient language.

The work of Adamo and Della Valle "NeologismiQuotidiani" [2, p. 254] based on the analysis of Italian daily newspapers for the period 1998-2003 comprises 5059 neologisms, including 600 borrowings and 135 calques of foreign origin, most of which are Anglicisms. Anglicisms enable society to realize three essential functions:

1) accumulation and comparison of information;

2) dissemination of knowledge;

3 ) actualization of political and cultural practices.

English borrowings used in printed press have predominantly denotative value. Having analyzed the terminology of Italian newspapers as well as the language spoken on the streets, on radio or TV, it is evident that commonly used borrowings have equivalents in Italian language, for example staff (It. personale). It is evidence that Anglicisms enrich the lexis not only semantically but also pragmatically. Every word carries signified associated with the history of the UK or the USA. In other words, global prestige of the UK and later of the USA led to the growth of popularity of English language that became fashionable among well-off people. In contemporary Italian language, the use of English borrowings in printed media enable journalists to transmit subliminal messages capitalizing on signified associated with the native speakers of English. For instance, the headline spotted in the newsletter "L'Espresso" $23^{\mathrm{d}}$ January 2018:

"Ifan del open source manifesteranno contro il boss della Microsoft".

En. "The open source fans will stage a demonstration against the Microsoft boss".

Apart from the fact that three out of ten words making up the headline are English borrowings, the words boss and fan, with Italian equivalents capo and sostenitorerespectively, are rather used for their connotative than denotative value. As compared with their Italian synonyms, these terms are marked with strong positive or negative connotation and can evoke certain feelings. Thus, the word fan bears a strong meaning of expectation and participation, whereas the word boss triggers negative associations with collocation mafia bosses. The title given above delivers a clear message of the author in respect to Bill Gates, therefore the choice of Anglicism demonstrates this necessity. 
In order to accomplish this goal, there was researched and analyzed the corpus of two main Italian newspapers, Corrieredella Sera and La Repubblica, for the period of $13^{\text {th }}-20^{\text {th }}$ June 2017. Quality and circulation were the primary criteria applied to the selection of the newspapers used in the empirical study. The considered newspapers were supposed to meet two principal requirements:

1. a national audience meaning the high scope of sales and dissemination throughout the Italian territory;

2. specific features of broadsheet newspapers, i.e. they should satisfy the needs of educated readership.

The latter criterion might be interpreted quite flexibly as contemporary high-quality newspapers tend to assume certain features of tabloids in order to acquire a wider readership. That means they do not ignore such aspects as scandals, celebrities, fashion, and the boundaries between broadsheet newspapers and tabloids are becoming more obscure. Nevertheless, the newspaper model is considered particularly relevant for evaluating the impact of English on contemporary Italian.

The concrete examples of the use of Anglicisms in the language of Italian press have been derived. In addition, Anglicisms have been allocated to two principal categories:

- Anglicisms with English signifiers, despite of being not fully equivalent to the original lexeme (for example, basket),

- and those (regardless the signifier equivalent to the Anglo-Saxon word), which do not retain the original signifier (for instance, loft), due to the willingness to introduce a foreign element into recipient language.

One of the principal motives of introducing the borrowings into the Italian press is the tendency to fill the gaps with foreign labels and tags. Having analyzed the collation of daily Italian newspapers and national magazines, it was concluded that the most of the borrowings are related to the sphere of politics, economy, labour and commerce, information technologies, fashion, entertainment, music, and sport. The obtained results are presented in the table 1.

Table 1

Examples of Anglicisms taken from the collation of daily newspapers and national magazines

\begin{tabular}{|c|c|}
\hline Category & Examples \\
\hline Politics & $\begin{array}{l}\text { antiglobal, bipartisan, devolution, embargo, intelligence, leader, leadership, soft pour, } \\
\text { summit, welfare, premier, governance, real politician, vice-premier, exit poll, no-global }\end{array}$ \\
\hline Information technologies & $\begin{array}{l}\text { blog, computer, e-waste, movie mode, multimedia card, slot, standby, zoom, file, } \\
\text { webgrandtour, scrapping, cyber-, display }\end{array}$ \\
\hline Entertainment & $\begin{array}{l}\text { best seller, gig, gossip, happening, musical, quiz, real tv, sequel, show, deejay, veejay, } \\
\text { pay tv, news, reality, fiction, reporter, prime time, set, scoop, horror, mass media, docu- } \\
\text { fiction, dossier }\end{array}$ \\
\hline Sport & $\begin{array}{l}\text { bomber, cross, corner fantabasket, gold, green, match, set, tackle, pressing, tunnel, } \\
\text { Champions League, team, sponsor, patron, penalty, ultras, escalation, compound, dop- } \\
\text { ing, antidoping, under } 21 \text {, club, hokey, rugby, basket, play out, play off, juniors, off- } \\
\text { shore, count down }\end{array}$ \\
\hline
\end{tabular}




\begin{tabular}{|l|l|}
\hline Mixed & Bye-bye, party, gay, bunker, arcigay, family day, transgender, clown, ticket, wildlife \\
& strikes, columnist, privacy, raider, gay pride, flop, spending review, racket, fist day, \\
& strip-tease, caos, bus, open road, clan, Todishire, record, soft, sin-in, black-bloc, test, no \\
comment, ogm-free, shock, broadcaster, access, grandtourist, snob, hotel, peer to peer, \\
baby-sitter, short story, kamikaze, clak, videopoker, ok, blitz, boom, big, pool, eros, \\
stop, week-end, check point, task force, junior, restyling, relax, acquagym, body work, \\
bluff, low cost, trend, cocktail, fast-food, shuttle
\end{tabular}

Another example of the English word with the relevant equivalent in Italian is the word leader, which could be easily traced in Italian press, meaning il capo, a ruler in political, military and labour-related discourse. This borrowing penetrated into Italian language in the XIX ${ }^{\text {th }}$ century to give a reference to Anglo-Saxon world where the politics and subsequently the military, commerce and employment sphere had reached a certain success and had been positively perceived by the Western world, thus, taking advantage of connotative meaning. However, being reiterated in mass media, this word acquires new emotional signified that immediately cognized by the readership. To sum up, applying certain words can send a clear and precise message that can create illusion or validate a new world.

Exploiting a connotative meaning of a borrowing with the purpose to exalt its sentimental value, a journalist can reveal a new truth to indulge the readership's curiosity. At the same time, surprisingly for an author, this phenomenon could have a positive flip-side. For example, the use of the words killer and baby in the headline 'baby-rapinatori' published in La Repubblica on June 17, 2007 served as a strategic maneuver to obtain something that the fraternity of the press had obtained a long time ago - information and first and foremost speculation. By using these terms, a journalist intends to keep the attention of the readership alive exploiting the connotative meanings of violence and victimization and to give an expression that the social environment in Italy is changing. Here we are not talking about the so-called foreignness of the terms alien to Italian language or of the words that became fossil. Borrowings unconsciously introduce new historic, cultural and social values, in particular, in the world of fashion. Using Anglicisms, the bosses of fashion industry automatically capitalize on importance and prestige of these terms when used in the source language. By means of Anglicisms, a journalist raises above the formal aspect, whereas being alien to the readership, those words strike creating a marked textual affect.

One of the numerous modifications introduced into complex and articulated periodicals, which had a propensity to the classic style decades ago, was the adoption of more agile and modern structures alternating paratassiand ipotassi of simplified type. Here occurs the syntactic change, being harmful for literary language and reflecting the patterns of spoken language. Emotional coloring of the news requires the use of more immediate and plain language as well as the relevant adjustment of the articles structure. In fact, neglecting traditional preference given to indirect discourse, a message is reformulated closer to the information source. This means the modern newspapers present the articles mostly in the form of an interview necessitating continuous alternation of direct discourse and editing. Thus, the main features of contemporary newspaper texts include:

- the preference is given to the use of nouns, not verbs;

- nominal style of information disclosure preconditioned by the necessity to inform and involve the readership;

- the excessive use of neology, mostly of English origin, which is one of the most prominent lexical features of the last decade, according to Illaria Bonomi [3, p. 25].

Having researched the Italian printed media texts, it was concluded that among the English terms, simple, compound and deverbal nouns accounted for $90 \%$, whereas the remaining 
$10 \%$ is related to attributes and objective complements. Preferential use of nouns results in creating the new style of writing, when the emphasis is given to maximizing the content and minimizing syntactic efforts. Thus, texts are becoming shorter but more effective in semantic and pragmatic aspects. Introduction of an English term allows avoiding phrase mongering and, at the same time, achieving the desired stylistic effect. For example, the compound word count down, attributed to American world of high-tech and military parlance, sounds more serious and provocative to a listener than its Italian equivalent contoallarovescia. Bringing in strong connotative meaning, Anglicisms function as a useful morphological and syntactical element, a tool to induce a desired reaction of the readership.

In the same manner there could be explained the necessity to use Anglicisms with denotative signified slightly different from the words in the source language. This is the case of the borrowings loft, testimonial, ticket, with the slightly altered meaning in Italian language. Another series of examples when the signifier is different from the source language include basket instead of English basketball, volley instead of volleyball, smoking for smoking-jacket, audience with the meaning of audience-rating, respectively (La Stampa, June 11, 2007).

A useful example to mention is the word relax used as a noun corresponding to English relaxation. It could be assumed that the deverbal substantive had been derived from the verb to relax without adding any affixes under the same pattern as for body-art and body-painting, for example. This illustrative example demonstrates how English words are usually shortened when adopted into Italian language. Also, the omission of the suffix could be explained by the willingness to emphasize that the used word is not a verb, like in the case with relax in "Le calzature relax"(Corrieredella Sera, June 10, 2007).

However, there could be spotted an opposite tendency to elongate English words though this is a rather rare phenomenon, e.g. lifting (found in the text "Il lifting faciale", Corrieredella Sera, June 16, 2007). The fact that the suffix -ing could form nouns, adjectives and verbs in English language is rather confusing for Italian speakers. This suffix can sometimes mislead a potential user and result in its erroneous use in noun-formation.

In fact, English language is very ductile in lexical morphology and its specific ability to transform verbs into nouns, with or without adding morphemes. This led to appearance of socalled false Anglicisms or even false phraseological units [8, p. 44]. False Anglicisms are either formally or semantically different from the original English words from which they are supposed to derive, so that both an English native speaker, proficient in Italian, and an Italian native speaker, proficient in English, would recognize them immediately in spoken or written registers [7].

This phenomenon turned out to be extremely productive in the sphere of advertisement, constantly popping up in Italian media texts. The following scrap can clearly demonstrate the excessive or even abusive use of Anglicisms:

"Con Alice Mobile, è tuttoinclusoalmeno di un euro al giorno e senzacosti di attivazione: pc cardo modem usb hi-speed per navigarefino a 3.6 mega e trafficodati per collegarsi ad internet e consultare la mail" (Corrieredella Sera, June 13, 2007).

En. Everything is included with Alice Mobile, for only 1 euro per day, excluding activation cost, pc cardo modem usb hi-speed for navigation up to 3.6 mega and the traffic providing connection to the internet and email usage.

Thus, Anglicisms possess a strong denotative value when expressing precise technical terms, in particular concepts and technologies originated abroad; the nouns and acronyms, following the sphere of advertising, allow formulating clear, concise and very convincing messages. The same could be said about newspaper headlines when it is required to "squeeze" the content of an article into limited space. Here, English nouns perform perfectly as they easily fit into syntactic structure, typical for newspapers. Not surprisingly, Anglicisms are of frequent occurrence in newspaper headlines and subheadings, like in the following examples taken from Corrieredella Sera, June 13, 2007: 
"Appelli bipartisan per la prof che puni il bullo".

En. "The calls of bipartisan for the professor punishing the ruffian".

"Milano smog record".

En. "Smog record of Milan".

In the same way as a novelist or a poet, a contemporary journalist has a certain degree of freedom to write everything he/she wants and to deliver a message to potential readership. This means that media texts not only reflect the reality of a certain society but also the models through the used terminology. In this aspect, English language represents a new world on cultural and social level, whereas on linguistic level - a communication mode with no barriers symbolizing an uncontrolled liberty. Having revolutionized the world, the Anglo-Saxon culture manifest itself in the use of the English language in daily Italian press that pursue one specific goal - freedom of speech or discussion.

Conclusions. The choice to use a borrowing has the advantage of not only introducing new denotative signified but also evoking certain emotions and feelings of the audience or readership. Journalists attempt to transmit a personal message, which is distinguished from the proper connotation and denotation of a term used in a source language.

Reasonable introduction and diffusion of Anglicisms allows for creating and delivering new messages that correspond to the needs of contemporary Italian society exercising more freedom. The English lexis in semantic and textual context provides more marked effect if compared to the equivalent words of Italian origin, partly due to denotative and associative meanings they carry, and partly because of syntactic flexibility of their adaptation. Rather than plug lexical or semantic holes ("tappare un buco"), Anglicisms facilitate creating a new type of texts, meaningful at communicative level. Here emerges the new essence of the language of Italian media texts - accessible light reading but informative and compulsive.

\section{REFERENCES}

1. Zabotkina, V. I. (1999). [Cognitive-pragmatic approach to neology]. Kognitivno-pragmaticheskij podhod $k$ neologii. Cognitive and pragmatic aspects of linguistic studies: Proceedings of scientific works, Kaliningrad university, pp. 3-9.

2. Adamo, G., Della Valle, V. (2007). Neologismi quotidiani. Undizionario a cavallo del millenio 1998-2003. Walter de Gruyter GmbH \& Co. KG, 1089 p. DOI: 10.1515/ZRPH.2007.582

3. Bonomi, I., Masini, A., Morgana, S. (2018). Riassunto la lingua Italianai mass media. Sintesi di Linguistica, $29 \mathrm{p}$.

4. Burke, P. (2006). The hybridization of languages in early modern Europe. European Review. Issue 14 (1), pp. 105-110. DOI: 10.1017/S1062798706000093

5. Coveri, L., Benucci, A., Diadori, P. (2009). Le varietà del Italiano. Manuale di sociolinguistica italiana. Roma: Bonacci Editore.

6. Fanfani, M. (2002). Reazioni italiani agli anglicismi. In San Vicente, Fèlix (red.). L'inglese e le alter lingue europee: studi sull'interferenza linguistica. Bolonia: Clueb, pp. 215-235.

7. Ferguson, R. (2019). Italian False Friends. Canada, University of Toronto Press. DOI: 10.3138/9781487595180

8. Furiassi C. (2017). Pragmatic borrowing: phraseological Anglicisms in Italian. In: Boggio, Cecilia, Molino, Alessandra (Eds.), English in Italy: Linguistic, Educational and Professional Challenges. FrancoAngeli, Milano, pp. 38-60.

9. Pulcini, V. (2019). Internationalisms, Anglo-Latinisms and other kinship ties between Italian and English. Studia Linguistica Universitatis Iagellonicae Cracoviensis, issue 136 (2), pp. 121-141. DOI: 10.4467/20834624SL.19.011.10606

10. Rogato, G. (2008). Anglicismi nella stampa Italiana. Italica, 85(1), pp. 27-36.

The article was contributed on July11, 2021

Статья поступила в редакцию 11.07.2021 


\section{Author information}

Sokolova, Alla Germanovna - Candidate of Technical Sciences, Associate Professor of the Department of Foreign Languages and Professional Communication, National Research Moscow State University of Civil Engineering, Moscow, Russia; e-mail: as.falconi@yandex.ru

\section{Сведения об авторе}

Соколова Алла Германовна - кандидат технических наук, доцент кафедры иностранных языков и профессиональной коммуникации Национального исследовательского Московского государственного строительного университета, г. Москва, Россия; e-mail: as.falconi@yandex.ru 